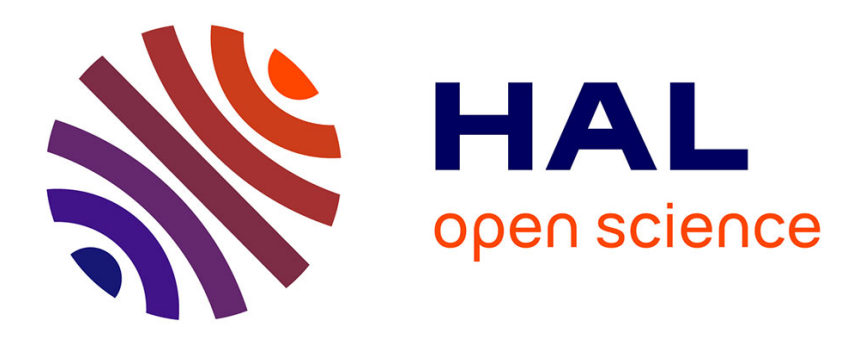

\title{
Fossil labidostomatid mites (Prostigmata: Labidostommatidae) from Baltic amber
}

\author{
J.A. Dunlop, M. Bertrand
}

\section{To cite this version:}

J.A. Dunlop, M. Bertrand. Fossil labidostomatid mites (Prostigmata: Labidostommatidae) from Baltic amber. Acarologia, 2011, 51 (2), pp.191-198. 10.1051/acarologia/20112006 . hal-01600007

\section{HAL Id: hal-01600007 https://hal.science/hal-01600007}

Submitted on 2 Oct 2017

HAL is a multi-disciplinary open access archive for the deposit and dissemination of scientific research documents, whether they are published or not. The documents may come from teaching and research institutions in France or abroad, or from public or private research centers.
L'archive ouverte pluridisciplinaire HAL, est destinée au dépôt et à la diffusion de documents scientifiques de niveau recherche, publiés ou non, émanant des établissements d'enseignement et de recherche français ou étrangers, des laboratoires publics ou privés. 


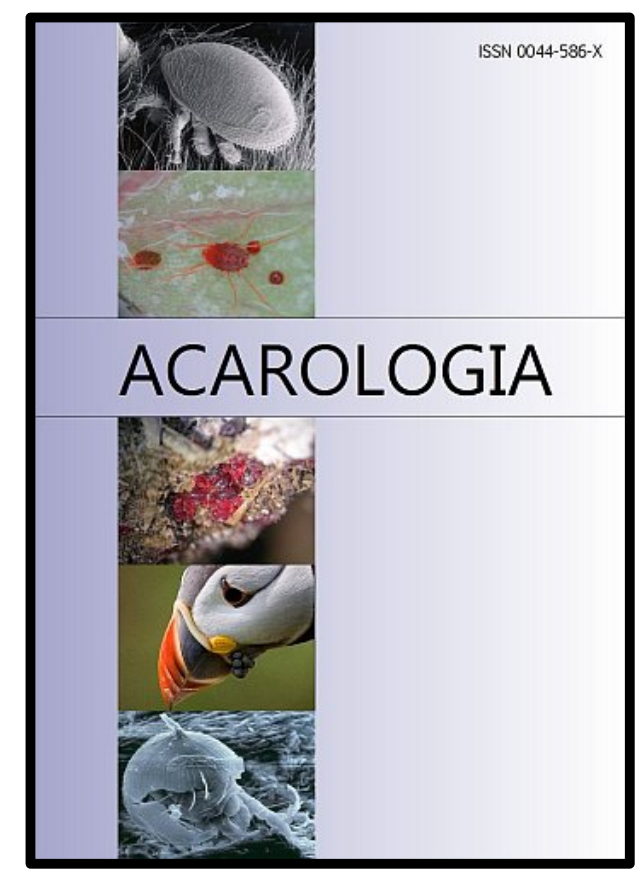

\section{ACAROLOGIA}

A quarterly journal of acarology, since 1959

Publishing on all aspects of the Acari

All information:

http://www1.montpellier.inra.fr/CBGP/acarologia/ acarologia@supagro.inra.fr

\section{OPEN ACCESS}

\section{Acarologia is proudly non-profit, with no page charges and free open access}

Please help us maintain this system by encouraging your institutes to subscribe to the print version of the journal and by sending us your high quality research on the Acari.

Subscriptions: Year 2017 (Volume 57): $380 €$ http://www1.montpellier.inra.fr/CBGP/acarologia/subscribe.php

Previous volumes (2010-2015): $250 € /$ year (4 issues)

Acarologia, CBGP, CS 30016, 34988 MONTFERRIER-sur-LEZ Cedex, France

The digitalization of Acarologia papers prior to 2000 was supported by Agropolis Fondation under the reference ID 1500-024 through the « Investissements d'avenir » programme

(Labex Agro: ANR-10-LABX-0001-01)
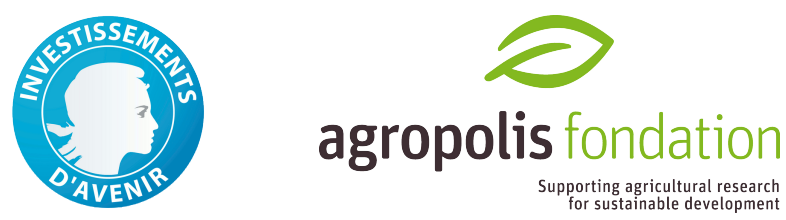

Acarologia is under free license and distributed under the terms of the

Creative Commons-BY-NC-ND which permits unrestricted non-commercial use, distribution, and reproduction in any medium, provided the original author and source are credited. 


\title{
FOSSIL LABIDOSTOMATID MITES (PROSTIGMATA: LABIDOSTOMMATIDAE) FROM BALTIC AMBER
}

\author{
Jason A. DUNLOP ${ }^{1^{*}}$ and Michel BERTRAND ${ }^{2}$ \\ (Received 17 January 2011; accepted 28 March 2011; published online 30 June 2011) \\ ${ }^{1}$ Museum für Naturkunde, Leibniz Institute for Research on Evolution and Biodiversity at the Humboldt University Berlin Invalidenstrasse 43, \\ D-10115 Berlin, Germany. jason.dunlop@mfn-berlin.de ( *corresponding author) \\ ${ }^{2}$ UMR5175 CEFE, Université Montpellier 3, Route de Mende 34199 Montpellier cedex5, France. michel.bertrand@univ-montp3.fr
}

ABSTRACT - Unequivocal fossil records of the mite family Labidostommatidae (Acari: Prostigmata: Trombidiformes) are described from Eocene Baltic amber. These two modern-looking specimens can be assigned to the extant genus Labidostomma Kramer, 1879 and are formally described here as Labidostomma paleoluteum sp. nov. Interestingly, the fossil specimens are associated in the amber piece with collembolans - a group on which modern labidostomatids readily prey — and other arthropods inhabiting upper soil layers.

KEYWORDS - Acari; labidostomatid mite; taxonomy; fossil; Eocene; Baltic amber

\section{INTRODUCTION}

Fossil mites are fairly rare, although perhaps not as rare as would be expected. A complete list of published records of fossil mites and other arachnids was recently made available as an online, and regularly updated, catalogue (Dunlop et al. 2011). There are undoubtedly further fossil mites - particularly in amber - which have yet to be formally described. Here, we focus on the Labidostommatidae, a trombidiform mite family. With respect to their fossil record, their presence in Baltic amber was mentioned by both Sellnick (1931) and Magowski and Tobolewski in Kosmowska-Ceranowicz, (2001); although neither study formally named the specimens nor included figures which would allow us to verify these identifications. Wunderlich (2002, fig. 3) figured an apparently predatory mite as "?Labidostemmidae" - the family name has under- gone a number of historical spelling variants - in Baltic amber, apparently in the process of attacking and/or feeding upon the opisthosoma of a theridiid spider. The same figure was reproduced in Wunderlich (2004, p. 127) as "Labidostommidae?".

Labidostommatidae is a distinctive and cosmopolitan group of heavily armoured, fast-moving, predatory mites (Walter et al. 2009); with about fifty extant species. Feider and Vasiliu (1969), then Bertrand (1990) revised the family, which is organized in a number of directions by adaptations to ecological conditions. Epi- or hemiedaphic species often show a wide distribution: i.e. most species of the genera Labidostomma or Eunicolina Berlese, 1911. Examples of species under eu-edaphic conditions include the genus Akrostomma Robaux, 1977 and troglophilous species like Labidostomma motasi Iavorschi, 1992. The distribution of the genera is 
wide. They may be cosmopolitan (i.e. Labidostomma) or widespread but typically Gondwanan, like the genera Sellnickiella Feider and Vasiliu, 1969 or Atyeonella Feider and Vasiliu, 1969. This can be interpreted as a consequence of the result of successive fragmentation of ancient and large areas.

In the fossil previously described (Wunderlich 2002), the disposition of the figured forelegs and the author's remarks about a heavily sclerotized cuticle are consistent with a labidostommatid: however, the published drawings are not of sufficient quality to confirm its assignment to any particular higher mite taxon (see also Discussion). Here, we describe unequivocal fossil representatives of Labidostommatidae based on two well-preserved inclusions in Baltic amber. These we recognise as a new species of the extant genus Labidostomma Kramer, 1879.

\section{MATERIALS AND METHODS}

The fossils described here originate from the Jörg Wunderlich amber collection and bear the inventory number F2152/BB/AC/CJW. Both mites are enclosed within in a single rectangular (ca $19 \mathrm{x}$ $9 \mathrm{~mm}$ ) piece of clear, yellow amber (Fig. 1), together with a staphylinid beetle, another mite (Eupodoidea) and some large collembolans as syninclusions. Other mites from the Wunderlich collection have been deposited in the Senckenberg Museum für Naturkunde Görlitz, Germany - and the present specimens may eventually be deposited here too (J. Wunderlich, pers. comm.). The fossils were drawn using a stereomicroscope with a camera lucida attachment and photographed under a stereomicroscope running the software package Leica Application Suite. A series of photographs were taken at different focal planes and combined into a single, final image using AutoMontage ${ }^{\circledR}$. A Wild Leitz 20EB microscope with modified lighting (reflect light) was used in Montpellier (10x6.4 or x16 or $25 \times 6.4$ or $\times 16)$.

A precise type locality for the specimens is not available, but much of the recently collected Baltic amber stems from the Kaliningrad region of the Baltic coast of Russia. Amber is difficult to date accurately, but Baltic amber is usually assigned to a
Palaeogene (Eocene) age of about $45 \mathrm{Ma}$. The fossils were compared to descriptions of modern taxa in the literature, together with extant labidostommatid material in MB's collection.

\section{LABIDOSTOMATIDES}

\section{Labidostomatides \\ Lindquist, Krantz \& Walter, 2009 \\ (= suborder Labidostommina Evans, 1992)}

\section{Family Labidostommatidae Oudemans, 1904}

\section{Genus Labidostomma Kramer, 1879}

Remarks — Bertrand (1990) recognised four labidostommatid genera: the Holarctic Eunicolina Berlese, 1911 characterized by multiplication of pustules and Akrostomma Robaux, 1977, with a dense reticulate cuticular pattern and characteristized by body shape and cheliceral morphology, the southern hemisphere Sellnickiella Feider and Vasiliu, 1969 - see also Bertrand (1997) - with loss of the gland-like organ, and the world-wide distributed Labidostomma. The latter was considered 'primitive' because of the retention of the main (plesiomorphic) characters shared by other representatives of the family, e.g. a primitive famulus, eyes, a pair of gland-like organs, chelicerae not modified; although some species acquired specialized characters that are considered as adaptations (neotaxy of gland-like organs, eye reduction, development of genual of PI, neotrichy, etc). For further taxonomic accounts of modern Labidostomma see, e.g., Bertrand (1981), Bertrand and Theron (1990), Iavorschi (1992) or Bertrand and Corpuz Raros (1997).

Note on the family and genus nomenclature: Etymology of the generic name Labidostomma refers to both Latin and Greek with Labidos referring to the large chelicerae and Stoma, stomatos, mouth. Berlese, Oudemans, Grandjean, and others selected the orthography with a single ' $\mathrm{m}$ ' - which is etymologically correct - whereas other authors imposed an erroneous orthograph (see e.g. the large mandibles of Labidostomis Chevrolat, 1837 (Insecta, Chrysomelidae)). Returning to the original generic description of Kramer (1879), we are forced to retain 


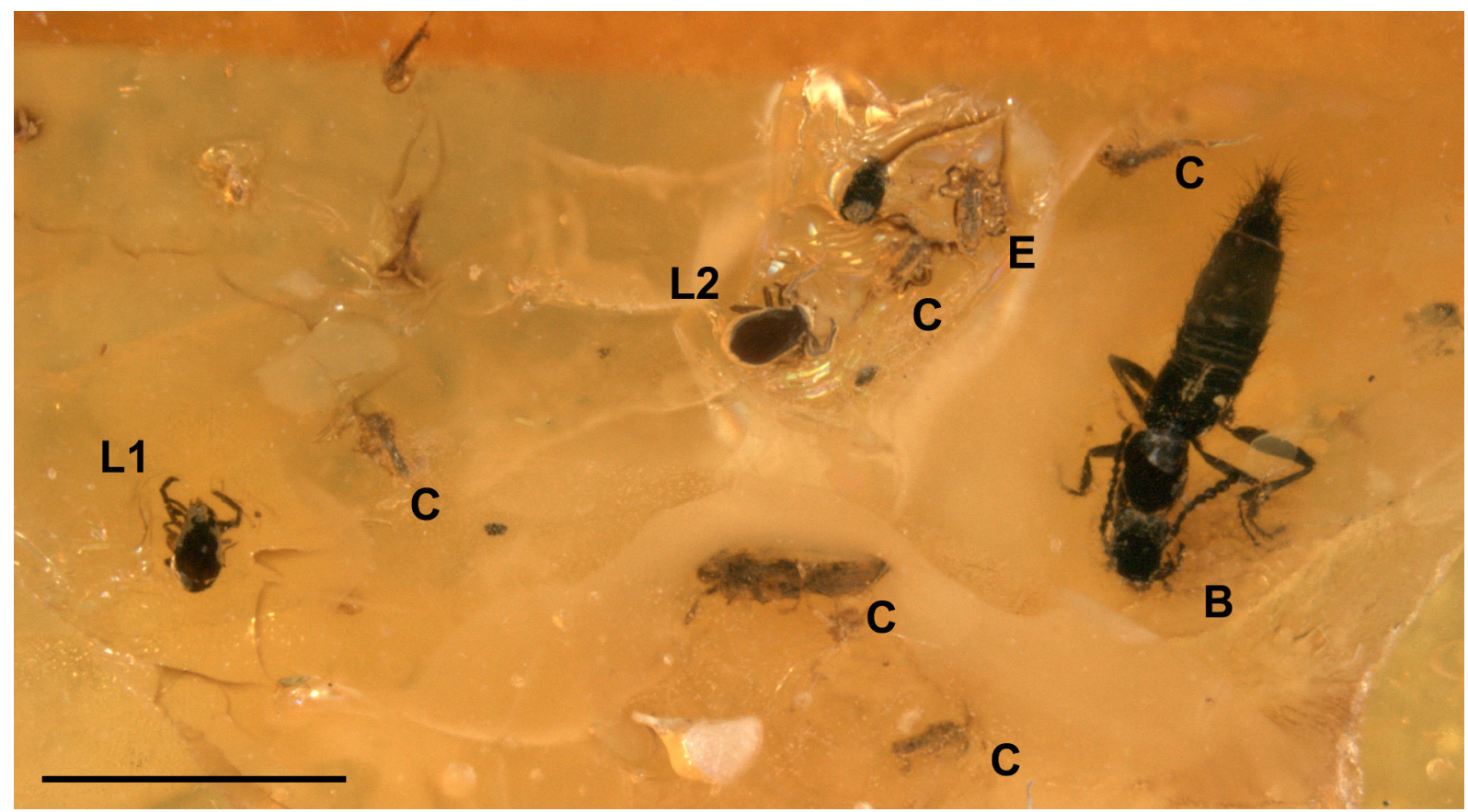

FIGURE 1: Overview of the amber piece including the two labidostommatid mites (L1: holotype; L2: paratype), both described here as new; a eupodoid mite (E), a number of colembollans (C) and a staphylinid beetle (B). The association of the mites with one of their typical prey items (collembolans) is noteworthy. Scale bar equals $2 \mathrm{~mm}$.

his initial orthographic mistake, i.e. Labidostomma, and treat Labidostommatidae (with a double ' $m$ ') as the valid family name. Note that this does not apply to the more recently established higher taxon (cohort) Labidostomatides.

\section{Labidostomma paleoluteum sp. nov. (Figures 1-4)}

\section{Etymology}

From the Greek palaios (Паגarós) 'old' and the suffix luteum derived from a similar-looking, and perhaps closely related, Recent species Labidostomma luteum Kramer, 1879.

\section{Material}

F21521/BB/AC/CJW. Two specimens (here designated as a holo- and paratype) within a single piece of amber (Fig. 1); together with a staphylinid beetle, one eupodoid mite and some collembolans as syninclusions. Baltic amber, precise locality not recorded; Palaeogene (Eocene).

\section{Description}

Notation follows F. Grandjean (1942). Dorsal view only visible in both specimens; body cuticle distinctly sclerotized, with alveolate ornamentation, clearly visible anteriorly, in central zone and in lateral fields on the opisthosoma (Figs 2-3). Anteriorly the body is rounded with a terminal eye clearly visible in a frontal position. Dorsal setation is distinguished and visible via the setae themselves or by the insertion points of missing setae: two pairs of trichobothria (boa and bop), rather long, each with at least two or three branches. Aspidosomal setae: $g a$ (long), ge, gm, gr as in L. luteum. Laterally the glandlike organ (pustule) is visible at least on the left side near the seta $g r$ which is long. Perturbation in ornamentation near the base of $g r$ interpreted here as the lateral eye. Opisthosomal setae: usual files of simple setae, lateral and dorsal $d a$ to $d e$ and la to $l e$.

A lateral cuticular accident on the posterior end of the dorsal shield could be a supplementary pustule (similar to L. jacquemarti Coineau, 1964 or vialeae Bertrand, 1981), in a postero-lateral position 

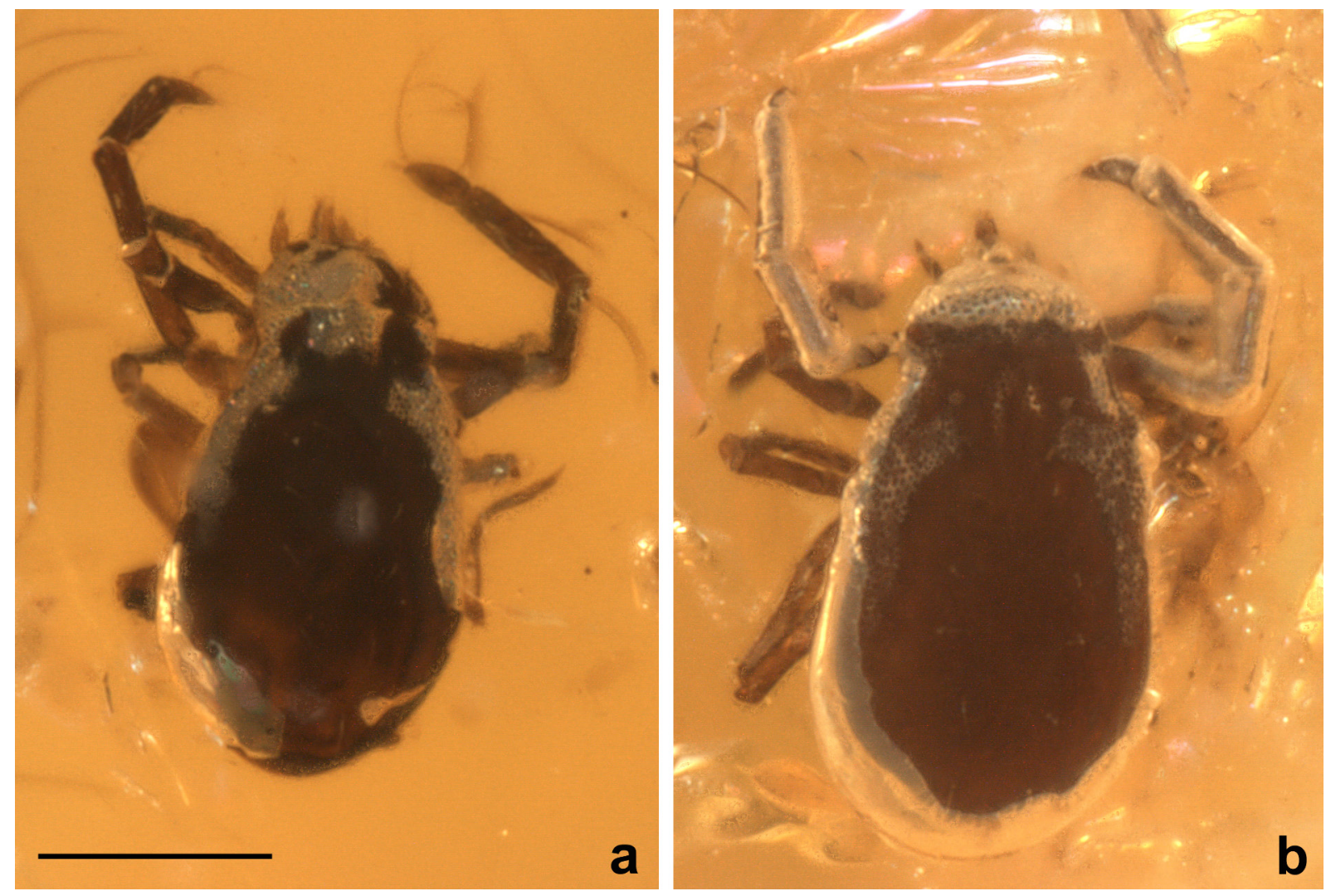

FIGURE 2: Labidostoma paleoluteum sp. nov. a - Holotype. b - Paratype. From Baltic amber (Palaeogene: Eocene). Both in dorsal view; scale bars equal $0.2 \mathrm{~mm}$.

on the dorsal shield. However, it could be an artefact; several Recent species express changes in cuticular cells in this same zone. Cuticle: when wellvisible reticulate with polygons. Ornamentation poorly visible on remainder of the dorsal shield which could be punctate or granulate. In recent labidostommids the cuticular polygons often vanish into granular, or increasingly less visible foveate, ornamentation from the peripheral to central dorsal shield.

Gnathosoma - Only visible in dorsal view. Fixed digit: extremity as in L. luteum or integrum dorsal subterminal setae $c h b$ was not visible. Setae cha long, proximally inserted on a tubercle (base hidden by dorsal shield). Palp visible from tibia to tarsus: habitual form, some unbroken setae present, especially the terminal seta that forms the terminal eupathidia characteristic of the family; a small lateral seta could represent the tarsal solenidion. Rest of setation compatible with usual pattern $(1,1,3$, $4+\omega)$.

Legs - The legs show habitual division into tripartite femora, and on the first pair articular function is devoted to telofemur-genu junction rather than to genu-tibia junction, as in the Recent species. PII-PIV claws not visible. PI: claw with two ungues, with long tarsal setae (simple setea). Terminal lateral setae long corresponding to the tarsal eupathidiae described from extant labidostommids. Chaetotaxy: Tibia: the usual setae are found; i.e. the long dorsal or ventral setae (terminal and median) and dosolateral and ventrolateral files. Tarsus poorly visible, but dorsally three hard to interpret anomalies could represent two dorsal tarsal solenidia, and the famulus that could be luteum-like; a barely visible rounded mass seems to be lightly discernible but would need more precise examination to confirm its identity. 

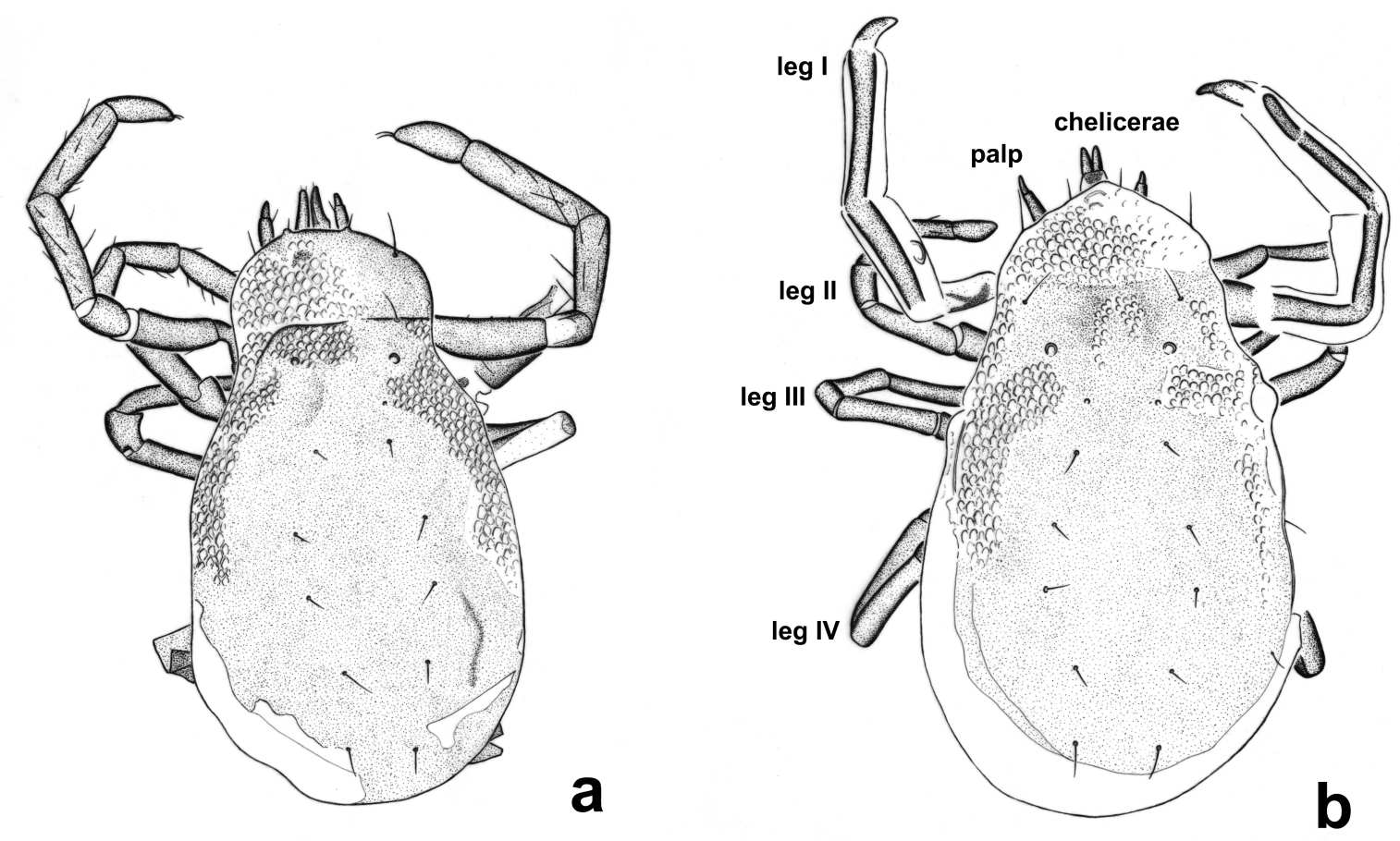

FIGURE 3: Interpretative camera lucida drawings of the specimens shown in Fig. 2. a - Holotype. b- Paratype. Both in dorsal view; scale bar equals $0.2 \mathrm{~mm}$.

Dimensions (all in $\mu \mathrm{m})$ - Total length 610. Dorsal shield $=550$ long, 320 wide.

Frontal eye 30 diameter; gland-like organ: diameter 27 - 30, setae: trichobothria length $60-70$, dorsal setae length about $50-60$. PI: tarsus length 65 (without claws); tibia length 150 - 160; genual length about 120; Femur: length 125. Cheliceral proximal seta length 75 . Terminal palpal seta length $40-50$.

\section{Diagnosis}

Although examination is only possible in dorsal view, the general morphology of this species corresponds to the pattern of the genus Labidostomma. It could not be confused with cornuta Canestrini et Fanzago, 1877 neither with the group of species related to L. integrum which are characterized by subterminal anterior eye, or cuticular pattern, length of tibia, development of lateral gland-like organ. Among the described species L. (Nicoletiella) paleoluteum n. sp. resembles L. luteum or L. denticu- lata Schrank, 1781 and should be classified in the same subgenus. Close to luteum in terms of size, dorsal ornamentation and appendages ornamentation, it differs from it and denticulata by absence of the frontal projections (cornua) that characterize these species. Lengths of articles in the first pair of leg are very similar to L. luteum, which is the most widely distributed species in Europe occurring from Mediterranean climates to Finland.

\section{DISCUSSION}

The Baltic amber deposit is the richest single source of fossil mites, probably since it has been intensively sampled for over 150 years. As in many other cases of Baltic amber mites (e.g. Bolland and Magowski 1990; Coineau and Magowski 1994; Witaliński 2000; Judson and Wunderlich 2003; Norton 2006), the fossils are essentially modern-looking and can be referred with some confidence to an extant genus. Labidostommatidae, and Labidostomma, thus date 


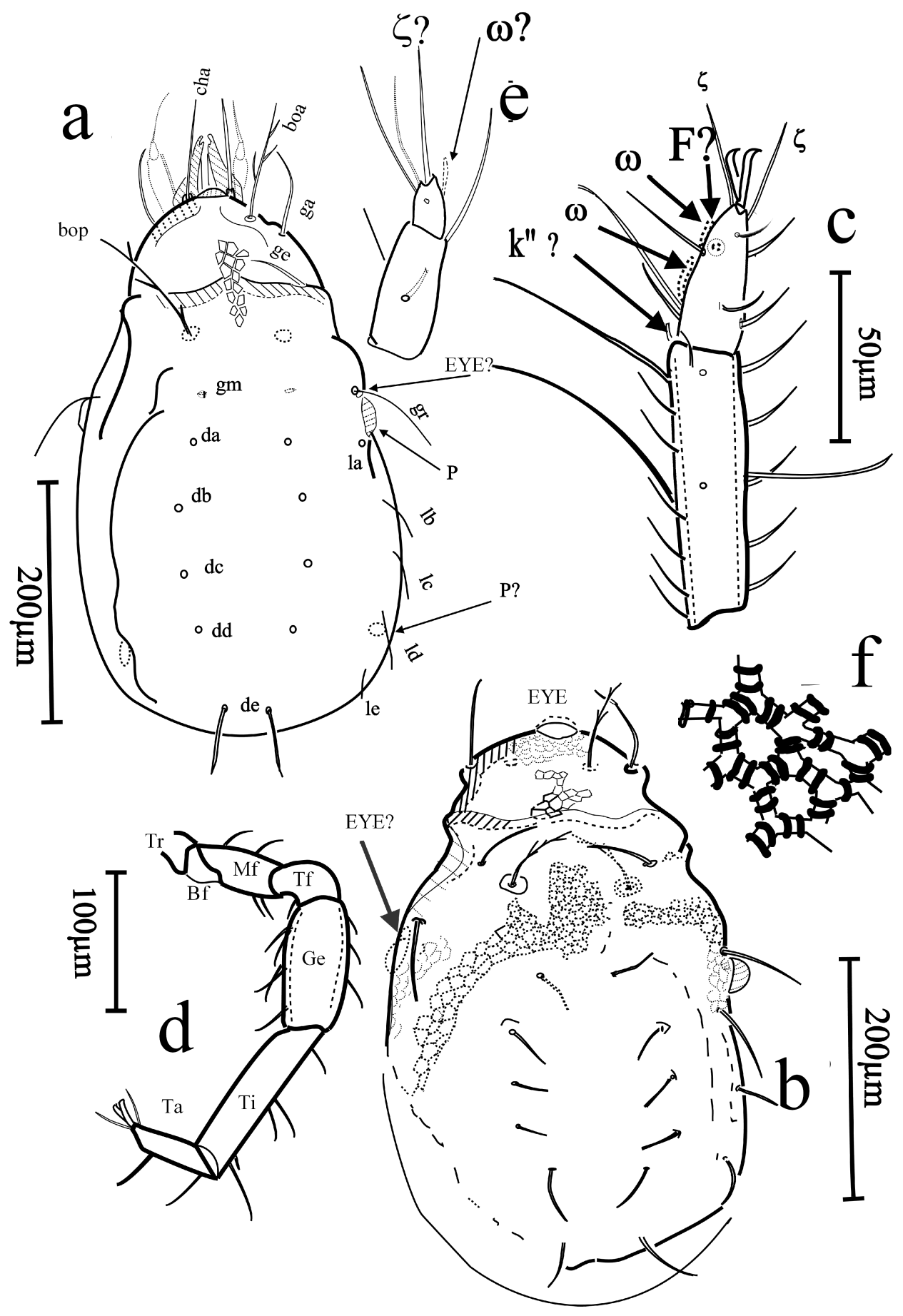

FIgURE 4: Morphological details. a-b - Dorsal view, specimen 1 and 2; c - P1 tibia and tarsus; $\mathrm{d}-\mathrm{P} 1$;. e - Palp terminal articles. $\mathrm{f}-$ Detail of anterodorsal sculpture. Abbreviations: $\zeta$ eupathidium, $\omega$ tarsal solenidion, boa-bop: trichobothria, cha: proximal cheliceral seta, F: famulus, $g a$, ge, gm, gr: aspidosomal dorsal setae, $k^{\prime \prime}$ : tibial famulus, $l a$ to $l e$ and $d a$ to $d e$ : lateral and dorsal files of setae, $P$ : posterolateral cuticular irregularity of dorsal shield. Tr, Bf, Mf, Tf, Ge; Ti, Ta: articles of PI (trochanter, basi, medio, telo femora, genu and tarsus) 
from at least the Eocene and show a strong degree of stasis; i.e. little morphological change over long periods of geological time. The modernity of the fossils suggests the group originated much earlier. The presence of large collembolans - and a large Eupodina mite - as syninclusions in the amber piece is of interest, characterizing the assemblage as an epigeic surface fauna, on which the carnivorous labidostommids could presumably have fed.

Wunderlich's $(2002,2004)$ observation of a putative labidostommid attacking a spider seems to us unlikely. Predatory behaviour of this nature is not known for modern labidostommids. Phoresy would be a possibility, but in general a mite attached by its mouthparts to a spider would be more consistent with the larva of something like an erythraeid or trombidid mite (both Parasitengona). We hoped to examine the original specimen on which this observation was based, but it could not be traced either in Wunderlich's own collection, or among the material originally from his collection now deposited in Görlitz (Axel Christian, pers. comm. 2011).

\section{ACKNOWLEDGEMENTS}

We thank Jörg Wunderlich for making this material available for study and drawing our attention to his 2002 publication, Axel Christian (Görlitz) for trying to trace material for us, David Walter for helpful initial remarks and the reviewers for valuable comments and hints about previous records of amber labidostomatids.

\section{REFERENCES}

Berlese, A. 1911 - Acarorum secies novae quindecim Redia, 7: 429-435.

Bertrand M. 1981 - Nouvelles espèces de Labidostomidae de Corse. Intérêt biogéographique -Acarologia 23: 27-38.

Bertrand M. 1990 - La famille des Labidostomidae Oudemans, 1904 (Acari: Actinedida). Révision des genres et sous-genres et catalogue des espèces décrites - Acarologia, 31: 31-38.

Bertrand M. 1997 - Sellnickiella (S.) biunguiculata n.sp., a noteworthy species of Labidostomidae from Australia
(Acari: Actinedida: Labidostomina) - Rec. West. Australian Museum, Perth, 18: 323-328.

Bertrand M., Corpuz Raros L.A. 1997 - Diversité du genre Labidostoma Kramer: nouvelles données apportées par l'étude de Labidostoma (Labidostoma) guadalupense n. sp. des Philippines (Acari, Actinedida, Labidostomatidae) - Acarologia, 38: 361-368.

Bertrand M., Theron P.D. 1990 - Nouveaux Labidostomidae d'Afrique Australe: le genre Labidostoma Kramer 1879 - Acarologia, 31: 247-257.

Bolland H.R., Magowski W.Ł. 1990 - Neophyllobius succineus n. sp. from Baltic amber (Acari: Raphignathoidea: Camerobiidae) — Entomol. Ber., 50: 17-21.

Coineau Y. 1964 -Un nouveau Labidostomidae à pustules multiples: Labidostoma jacquemarti n. sp. - Rev. Biol. Ecol. Sols, 1: 543-552.

Coineau Y., Magowski W.Ł. 1994 - Caeculidae in amber - Acarologia, 35: 243-246.

Dunlop J.A., Penney D., Jekel, D. 2011 - A summary list of fossil spiders and their relatives. In: Platnick N.I. (Ed.) The world spider catalog, version 11.5 American Museum of Natural History, online at (http://research.amnh.org/entomology/spiders /catalog/index.html.

Feider Z., Vasiliu N. 1969 - Révision critique de la famille des Nicoletiellidae - Proc. $2^{\text {nd }}$ Int. Congress Acarology: Sutton Bonington, England 1967. Acad. Kiado, Budapest: 202-207.

Grandjean F. 1942 - Observations sur les Labidostomidae (2e Série) - Bull. Hist. nat. Paris 14, 3: 183-192.

Iavorschi V. 1992 - Labidostoma motasi n.sp. (Nicoletiellidae) a new species of the mite of Romania - Trav. de 1'Instit. de Spéleol. "Emile Racovitza", Bucharest., 31:47-51.

Judson M., Wunderlich J. 2003 - Rhagidiidae (Acari, Eupodoidea) from Baltic amber - Acta Zool. Cracov., 46 (suppl.-Fossil Insects): 147-152.

Kramer P. 1879 - Neue Acariden — Arch Naturgesch., 45: 13-16.

Lindquist E.E. Walter D.E., Krantz G.W. 2009 - Classification - In: Krantz G.W., Walter D.E. (Eds). A Manual of Acarology, 3 edit. Lubbock: Texas Tech. University Press. p. 97-103.

Magowski W., Tobolewski J. 2001 - Superordo Acarina mites - In: Kosmowska-Ceranowicz, B. (Ed.) The amber treasure trove. Part I. The Tadeusz Giecewicz's collection at the Museum of the Earth, Polish Academy of Sciences, Warsaw. Museum of the Earth Documentary Studies, 18: 28-32.

Norton R.A. 2006 - First record of Collohmannia (C. schusteri n. sp.) and Hermannia (H. sellnicki n. sp.) from 
Baltic amber, with notes on Sellnick's genera of fossil oribatid mites (Acari: Oribatida) - Acarologia, 46: 111-125.

Oudemanns A.C. 1904 - Notes on Acari. 2e Série - Tijdsch. Entom., 46: 93-134.

Robaux P. 1977 - Observations sur quelques Actinedida (= Prostigmates) du sol d'Amérique du Nord. VI. Sur deux espèces nouvelles de Labidostommidae (Acari) - Acarologia, 18: 442-461.

Sellnick M. 1931 - Milben im Bernstein - BernsteinForschung, 2: 148-180.

Walter D.E., Lindquist E.E., Smith I.M., Cook D.R., Krantz G.W. 2009 - Order Trombidiformes - In: Krantz G.W., Walter D.E. (Eds). A Manual of Acarology, 3rd edit. Lubbock: Texas Tech. University Press. p. 233420.

Witaliński W. 2000 - Aclerogamasus stenocornis sp. n., a fossil mite from the Baltic amber (Acari: Gamasida: Parasitidae) - Genus, 11: 619-626.
Wunderlich J. 2002 - Ant mimicry by spiders and spidermite interactions preserved in Baltic amber (Arachnida: Acari, Araneae) — In: Toft S., Scharff N. (Eds) European Arachnology 2000. Aarhus: Aarhus University Press. p. 355-358.

Wunderlich J. 2004 - Parasites, parasitoids and other enemies of fossil spiders and their egg sacs - In: Wunderlich J. (Ed.) Fossil spiders in amber and copal Beit. Aranaeol., 3A: 115-125.

\section{COPYRIGHT}

$(\mathrm{cc})$ EY-NG-ND Dunlop and Bertrand. Acarologia is under free license. This open-access article is distributed under the terms of the Creative Commons-BY-NC-ND which permits unrestricted non-commercial use, distribution, and reproduction in any medium, provided the original author and source are credited. 